\title{
Implementation of Digital Marketing for Economic Recovery of Micro Small Enterprise after Covid-19
}

\author{
Febrianur Ibnu Fitroh Sukono Putra, Risanda Alirastra Budiantoro, \\ Awanis Linati Haziroh
}

\begin{abstract}
Management Department, Economics and Business Faculty, Dian Nuswantoro University
St. Imam Bonjol No. 207, Pendrikan Kidul, Central Semarang, Semarang City, Central Java, 5013, Indonesia
\end{abstract}

\begin{abstract}
The most important thing that needs to be considered in a pandemic is the economic sector recovery mechanism due to the lockdown policy, especially in Indonesia. This lockdown policy is an anticipatory step from the Government to the chainbreak of Covid-19s spread. The application of digital marketing at a strategic level is carried out as an alternative solution to traditional marketing becomes more comprehensive. So, this research aims to build and develop a model that is ideal for micro-enterprises adoption in Indonesia. This research uses an exploratory qualitative approach. Data sources were obtained through observation, interviews, and literature studies. The micro-enterprise adoption process comprises (1) the initiation phase, (2) the decision-making phase, and (3) the outcomes phase. The advantages of this program are (1) increase trust from existing customers and acquiring potential new customers, (2) novelty in technological sophistication, (3) expanding market share, and (4) increasing competitiveness.
\end{abstract}

DOI: $10.18421 /$ SAR43-07

https://doi.org/10.18421/SAR43-07

Corresponding author: Febrianur Ibnu Fitroh Sukono Putra,

Dian Nuswantoro University. Semarang City, Central Java, 5013, Indonesia

Email: fbr10@dsn.dinus.ac.id

Received: 29 July 2021.

Revised: 10 September 2021.

Accepted: 16 September 2021.

Published: 23 September 2021.

(c) (1) (5) 2021 Febrianur Ibnu Fitroh Sukono Putra, Risanda Alirastra Budiantoro \& Awanis Linati Haziroh; published by UIKTEN. This work is licensed under the CCBY-NC 4.0.

The article is published with Open Access at www.sarjournal.com
Keywords - Adoption, Covid-19, Digital Marketing, Micro-enterprise.

\section{Introduction}

The Covid-19 pandemic that has been taking place since December 2019 is increasingly widespread, including in Indonesia. As of August 12th, 2020, the number of suspects of the Covid-19 pandemic globally reached $20,539,733$ people, with a death rate reaching 746,246 cases or 3.63 percent, while the recovery rate was $13,457,923$ cases or 65.52 percent. Historically, this figure has continued to increase since the first cases occurred in Wuhan, Hubei Province, China [1]. Things that need to be considered when a case is an epidemic are an effective recovery mechanism, especially in the economic sector that is shaken due to the Large-Scale Social Restriction movement or lockdown that was imposed in several regions, including Indonesia. This lockdown policy is an anticipatory step from the Government to break the chain of the spread of Covid-19 in Indonesia, but the consequences will directly affect the macroeconomy's performance [2]. In this case, the micro-enterprise sector has become the focus of the attention of the Government, considering that the contribution of this sector has a dominant influence on GDP and is a mainstay in employment [3].

In practice, even in normal conditions, microenterprise often experience various difficulties in running their business, especially in the current pandemic condition. Micro-enterprise actors need some adjustments due to the Covid-19 pandemic, such as decreased purchasing power, a quiet market share, and other constraints in the production and distribution process. This program has to be done as an effort so that micro-enterprise actors can survive uncertain macroeconomic conditions, prevent bankruptcy, and increase their competitiveness [4]. One alternative solution that can be utilized by Micro-enterprise is by implementing a new 
technology-based marketing system to maximize existing marketing strategies, where the Indonesian Government initiated the adoption of a digital marketing program [5].

However, many MSMEs are struggle to sustain or to expand due to many constraints they face, especially lack of access to bank loans, difficulties in marketing, and limited access to advanced technologies and skilled workers. The Ministry of Cooperatives and Small and Medium Enterprises shows the data of micro-enterprise in Indonesia at 2015-2019 between the unit and the people (Table 1).

Table 1. Data of Micro-enterprise Enterprise in Indonesia at 2015-2019

\begin{tabular}{|c|c|c|c|c|c|}
\hline & 2015 & 2016 & 2017 & 2018 & 2019 \\
\hline $\begin{array}{c}\text { Total of Micro-enterprise in } \\
\text { Indonesia (unit) }\end{array}$ & $59,262,772$ & $61,651,177$ & $62,922,617$ & $64,194,057$ & $66,023,980$ \\
\hline $\begin{array}{c}\text { Total of Micro-enterprise in } \\
\text { Indonesia (people) }\end{array}$ & $110,807,864$ & $112,828,610$ & $116,431,224$ & $116,978,631$ & $113,579,550$ \\
\hline
\end{tabular}

Source: (Ministry of Cooperatives and Small and Medium Enterprises, 2019).

It is maximizing the digital marketing adoption program by micro-enterprise in Indonesia to be competitive, superior, and creative in reducing their operational marketing costs, making it easier to access data and expand market reach [6]. The application of digital marketing at this strategic level as a complement to traditional marketing and business strategies is becoming more comprehensive [7]. The thing that needs to be prepared is integrating the program with the Indonesian Government in preparing this program ideally, considering that access to technology is also one of the biggest obstacles for Micro-enterprise [8]. Based on the existing problems, to encourage exploration as a digital marketing process that will be adopted by Micro-enterprise to survive this Covid-19 pandemic so that hope can be a foundation in business sustainability. So, this research aims to develop and compile an ideal model in the adoption of digital marketing programs in micro-enterprise in Indonesia.

\section{Literature Review}

The era of the industrial revolution 4.0, digitization has become an essential aspect in various aspects of life. This era is marked by the development of the digital economy, artificial intelligence, big data, and robotic, so naturally, this era is known as a disruptive innovation [9]. The form of its application applies to large scale industries and applies to the micro-enterprise sector. However, the problem is that in discussing the micro-enterprise sector, there is no standard and universally applicable definition regarding the boundaries for actors in this sector in Indonesia [10]. In essence, the classification of this sector is based on the consideration of the value of net assets owned and the value of sales proceeds obtained by micro-enterprise as stated in Law no. 20 of 2008, concerning Micro-enterprise, with the following details (see Table 2):

Table 2. Definition and Criteria of Micro-Enterprise

\begin{tabular}{|c|c|}
\hline Scale & Definition and Criteria \\
\hline $\begin{array}{l}\text { Micro- } \\
\text { enterprise }\end{array}$ & $\begin{array}{l}\text { - Productive businesses are individually owned or individually owned } \\
\text { companies that meet the applicable micro-enterprise criteria (generally a type } \\
\text { of home industry consisting of 1-4 people) } \\
\text { - Total net assets owned in this sector reach a maximum of IDR } 50 \text { million (this } \\
\text { amount does not include land and buildings from the place of business) } \\
\text { - Get maximum sales of IDR } 300 \text { million in one year }\end{array}$ \\
\hline
\end{tabular}

Source: (Law no. 20 of Micro-enterprise, 2008)

Facing the Industrial Revolution era, the Government of Indonesia is serious about preparing well by empowering Micro-enterprise in Indonesia so that they can compete. With the program as the adoption of digital marketing programs for microenterprise initiated by the Indonesian Government, one of them is a form of concrete support from the Indonesian Government in improving the economic sector, especially for Micro-enterprise. Besides, this program is also an update in the development of smart countries to build an ideal program adoption model. This program is essential and urgent because a smart city can contribute 6.52 percent to regional economic growth [11]. In line with this, the program could become a potential platform for $113,579,550$ micro-enterprises in Indonesia. Several aspects are emphasized related to the program's contribution to the smart countries' concept (see Table 3 ). 
Table 3. Smart Countries Program

\begin{tabular}{|c|l|l|}
\hline No & \multicolumn{1}{|c|}{ Aspect } & \multicolumn{1}{|c|}{ Include } \\
\hline 1 & Smart governance & Finance, information disclosure, licensing, public information centers, public services \\
\hline 2 & Smart branding & Micro-enterprise Sector, regional tourism, e-mail \\
\hline 3 & Smart economy & Crafts, souvenir centers, processed snacks \\
\hline 4 & Smart giving & Population, layout, Indonesian cards are great \\
\hline 5 & Smart society & Thematic countries, job search data, great gates \\
\hline
\end{tabular}

Source: Indonesia Government, 2019.

The technical implementation of this program is in the form of an electronic catalogue to provide various sources of information related to products offered to Micro-enterprise in Indonesia in a comprehensive manner starting from the list, type, technical specifications, and price of the product. The advantage of adopting this digital-based marketing program is that it can be an effective medium in making buying and selling transactions, ordering from these micro-business products. This program is a marketplace managed by the Government of Indonesia, especially the Office of Cooperatives and Micro-enterprise in Indonesia, which is not commercial, meaning that the management of incoming order transactions is directly forwarded to Micro-enterprise without being charged a penny.

The program adoption process is the initial stage for Micro-enterprise in accepting innovations initiated by the Indonesian Government. This adoption's success depends on the ability (attitude, motivation, knowledge, and skills) of the microenterprise actors as the adopting party, which is synergized with socialization as an introduction stage with the Indonesian Government [12]. The purpose of this digital marketing system is market segmentation which will be increasingly developed because this electronic catalog system does not limit the extent of marketing coverage so that customers from various regions can access it easily. Besides, the marketing strategy can transparently take place and emphasize the operational costs incurred by Microenterprise [13].

The research method attempts to find, develop, and test the truth of knowledge in scientific ways. This study uses an exploratory qualitative approach to identify a comprehensive adoption process related to digital marketing to micro-enterprise players in Indonesia as a form of economic recovery during the Covid-19 pandemic. Qualitative research is intended to gather information about the status of an existing symptom, namely the state of symptoms according to what they were at the time the research was conducted. Therefore, qualitative research can reveal phenomena in a subject that want to study in-depth [14].

\section{Types and Sources of Data}

The type of data used is a combination of primary data on results and secondary data that supports studies in formulating ideal modeling for digital marketing adoption in Indonesia's micro-enterprise sector. In this case study research, data is obtained through observation (field research), interviews, and other literature studies.

a. Direct observation technique: the researcher directly observes the object under study, namely the practice of micro-enterprise actors in several sub-districts in Indonesia, with the sampling method using non-probability sampling (snowball), a method used to identify, select and take samples in a network or a continuous chain of relationships.

b. The interview technique is carried out in-depth (depth interviews) of micro-enterprise actors in Indonesia when the researcher makes direct observations, with questions asked and that include:

- How do you find out about digital marketing adoption?

- What do you do once you are well informed about digital marketing adoption? Are you immediately interested in adopting?

- What attracted you and what made you decide to adopt digital marketing?

- What are the stages of doing digital marketing? Are you building your own or using a vendor at this point?

- What are the benefits of adopting digital marketing?

c. Data collection techniques through literature studies are obtained from the results of reports published by agencies involved in implementing digital marketing adoption as well as some literature.

\section{Research Flow and Conceptual Framework}

The research flow scheme starts with the potential micro-enterprises in Indonesia, where the majority come from home industries. The Indonesian government provides strategic solutions in a model 
as a form of digital marketing adoption for microenterprises in Indonesia who are potentially affected by the Covid-19 pandemic.

The adoption of this digital marketing program was initiated by the Government of Indonesia to increase digital marketing programs for microenterprises affected by the Covid-19 pandemic. Through the adoption of this program, it is hoped that the marketing system and digital-based business strategy run by micro-enterprises in Indonesia will be sufficient. So that in the end, there was a strengthening of the business of micro-enterprises in Indonesia in fighting the Covid-19 pandemic, which made it easier to access data and expand market reach.

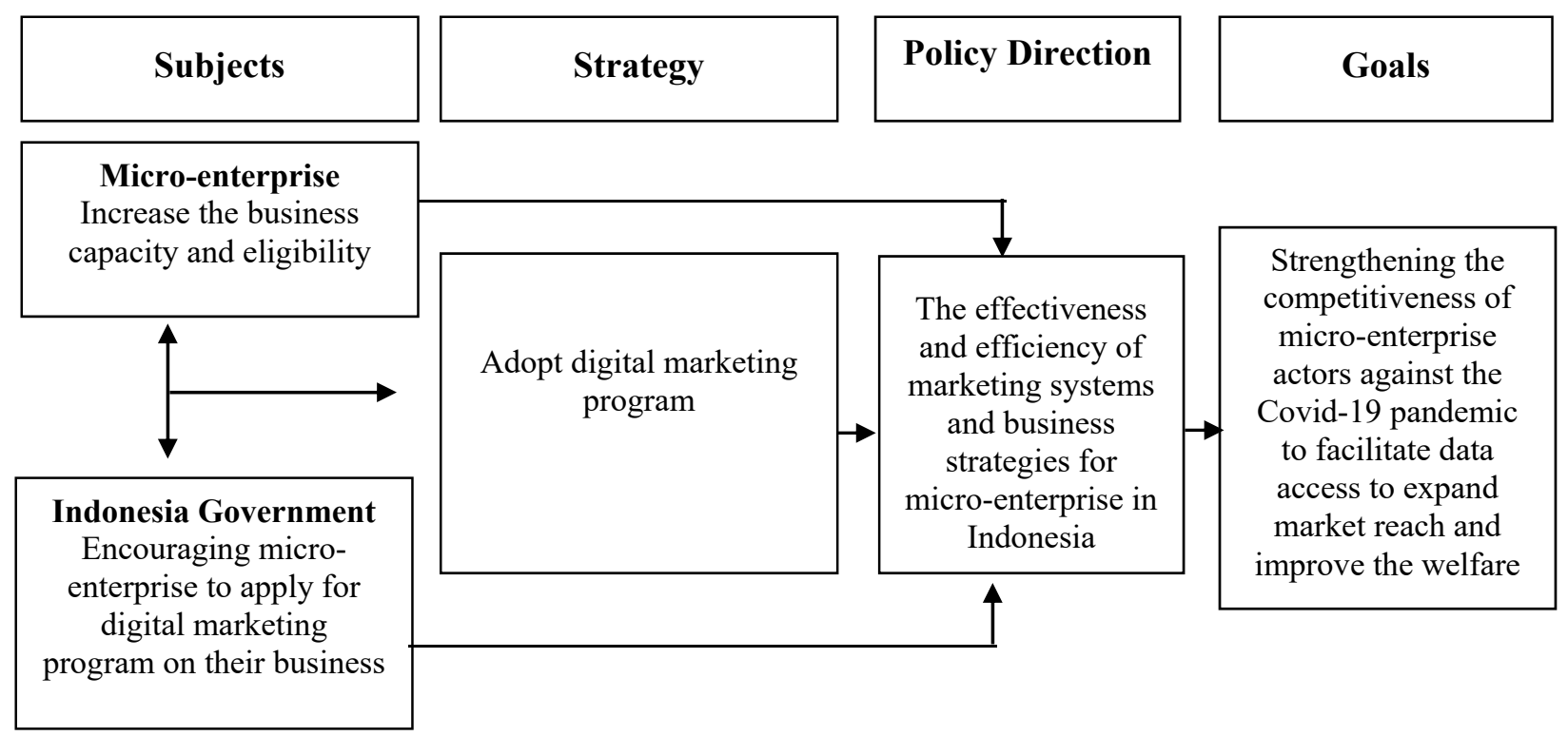

Figure 1. Conceptual Framework in Adopting Digital Marketing Programs to Micro-enterprise in Indonesia

\section{Opportunities and Constraints Faced by Micro- enterprises and Small Businesses in Indonesia}

This program's adoption process is designed to assist micro-enterprises in Indonesia, especially in optimally conducting digital marketing. This program is essential, considering the massive number of micro-enterprise players in Indonesia. Data from the Indonesian Cooperatives and Micro-enterprise Service (2019) shows that micro-enterprise actors are relatively balanced between sub-districts, where Central Java has the highest number of micro- enterprise players of 2,814, and South Borneo has the least number of micro-enterprise players are amounting to 429 business actors. Furthermore, when viewed from the income side, based on the type of business run by micro-enterprises in Indonesia, it tends to fluctuate with a positive trend (see Table 4). The top five positions in the micro-enterprise sector with the highest sales turnover are achieved by food, followed by handicrafts, crafts, fashion, and beverages. It means that these five sectors are the program's superior products.

Table 4. Indonesian Micro-enterprise Income Turnover, 2015-2019

\begin{tabular}{|l|c|c|c|c|c|}
\hline Commodities & $\mathbf{2 0 1 5}$ & $\mathbf{2 0 1 6}$ & $\mathbf{2 0 1 7}$ & $\mathbf{2 0 1 8}$ & $\mathbf{2 0 1 9}$ \\
\hline Handy Craft & 33.549 .450 .000 & 32.531 .600 .000 & 31.513 .750 .000 & 30.495 .900 .000 & 29.478 .050 .000 \\
\hline Batik & 1.301 .391 .000 & 1.310 .995 .700 & 1.320 .600 .400 & 1.330 .205 .100 & 1.339 .809 .800 \\
\hline Drink & 725.000 .000 & 702.550 .000 & 680.100 .000 & 657.650 .000 & 635.200 .000 \\
\hline Food & 16.307 .671 .500 & 19.858 .674 .400 & 23.409 .677 .300 & 26.960 .680 .200 & 30.511 .683 .100 \\
\hline Fashion & 867.976 .150 & 1.011 .811 .380 & 1.155 .646 .610 & 1.299 .481 .840 & 1.443 .317 .070 \\
\hline Convection & 224.500 .000 & 214.001 .400 & 203.502 .800 & 193.004 .200 & 182.505 .600 \\
\hline Craft & 1.310 .951 .000 & 1.515 .892 .900 & 1.720 .834 .800 & 1.925 .776 .700 & 2.273 .475 .547 \\
\hline Soap & 1.720 .500 & 1.680 .300 & 1.640 .100 & 1.599 .900 & 1.559 .700 \\
\hline Services & - & - & - & - & - \\
\hline
\end{tabular}

Source: (Ministry of Cooperatives and Small and Medium Enterprises, 2019). 


\section{The Influence of the Covid-19 Pandemic on Business Practices of Micro-enterprises in Indonesia}

The Covid-19 pandemic has taken place since December 2019, it has significantly affected the economic sector both nationally and regionally. In this case, large companies were not only felt, but the Covid-19 pandemic also destroyed micro-enterprises in Indonesia [15]. According to data Ministry of Cooperatives and Micro-enterprises of Indonesia (2020), 1,538 micro-enterprise actors were recorded as being affected by this pandemic, one of which is the difficulty in marketing their business products. This problematic economic condition has disrupted several micro-enterprise business practices and has even stopped operating, including micro-enterprises engaged in food processing or culinary and craft arts and crafts industries [16].

The problems faced by micro-enterprises in Indonesia are divided into two aspects, namely, external and internal (see Table 5). The internal problems of MSMEs enterprise are seen from capabilities, core competencies, and information and knowledge resources so that the formulation and implementation of business strategies are hampered, while from the external side, all forms of problems that can threaten business continuity come from outside [17].

Table 5. Problems Faced by Micro-enterprises in Indonesia

\begin{tabular}{|c|c|}
\hline \multicolumn{1}{|c|}{ Internal } & External \\
\hline Lack of innovation in entrepreneurship & $\begin{array}{c}\text { Development policies for micro-enterprise and } \\
\text { small actors are still not responsive. }\end{array}$ \\
\hline $\begin{array}{c}\text { Because the production capacity is small, it results } \\
\text { in diseconomies of scale. }\end{array}$ & $\begin{array}{c}\text { Lack of external contributions in supporting } \\
\text { micro-enterprise development. }\end{array}$ \\
\hline $\begin{array}{c}\text { Limited capital } \\
\text { The quality of human resources is low, which } \\
\text { results in the quality of the products not being } \\
\text { maximized. }\end{array}$ & Threats from imported products are similar. \\
\hline $\begin{array}{c}\text { Availability of raw materials in the production } \\
\text { process }\end{array}$ & Difficult to expand the markets. \\
\hline $\begin{array}{c}\text { Because it is not yet effective and efficient in the } \\
\text { production process, the production costs are high, } \\
\text { so the bought and sold products are relatively } \\
\text { expensive. }\end{array}$ & $\begin{array}{c}\text { The financing process carried out by formal } \\
\text { financial institutions is still convoluted and } \\
\text { imposes high-interest costs. }\end{array}$ \\
\hline $\begin{array}{c}\text { The use of technology in the production process is } \\
\text { relatively low. }\end{array}$ & \begin{tabular}{c} 
Ponstions \\
\hline
\end{tabular} \\
\hline
\end{tabular}

Source: Primary Data, 2020.

\section{Digital Marketing Program Overview}

As the Indonesian Government has to manage a medium for conducting digital marketing for microenterprise in Indonesia, the Indonesian Government's adoption through a single online submission through the Cooperative and Micro-enterprise Service to minimize errors modeling system formed. The emphasis is on systematic data collection on microenterprise actors who are business partners. Their business development can be monitored and it provides input and direction in decision making as a strategic plan for empowering micro-enterprise players in Indonesia [18]. The digital marketing program is an innovative means for the Government of Indonesia to carry out digital marketing in an electronic catalogue to buy and sell. Orders to microenterprise players can be realized immediately so that the multiplier effect can help smooth business ventures, especially when the economy is sluggish due to the Covid-19 pandemic [19]. Therefore, the
Government of Indonesia uses a digital marketing program as one of the facilities in making electronic catalogues that are used for superior local products, especially for culinary products, crafts, fashion, and the creative economy of micro-enterprises in Indonesia.

As an electronic-based catalogue owned by the Government of Indonesia, several operational procedures have to be followed. The operating standard aims to ensure that this program does not harm anyone, including sellers, buyers, and service providers. The goal of this digital marketing program is that the benefits can be felt directly, for buyers (getting superior products from the desired microenterprise players), for sellers (increasing their business competitiveness due to the Covid-19 pandemic), and for the Government of Indonesia (providing services prima by empowering microenterprise actors in the adoption of digital marketing through electronic catalogues). Several things need to be underlined regarding adoption, as follows [20]: 
a. This electronic catalogue acts as a medium for ordering (purchasing orders) for the Indonesian Government or the general public.

b. Products traded are the superior products of micro-enterprises in Indonesia and have registered their membership.

c. The Government of Indonesia is fully responsible for managing this program through the Office of Cooperatives and Micro-enterprises. The manager acts as a guarantor for buyers and sellers to get a sense of security and comfort when buying and selling transactions in the program.

d. The electronic catalogue can be accessed by anyone, anytime and anywhere, to increase microenterprise players' opportunities to market their products digitally. When a transaction requires a delivery service, shipping charges can be communicated directly between the buyer and the seller without going through an intermediary between the Indonesian Government or the Cooperative and Micro-enterprise Office.

The ease of joining the program is one of its advantages (see Table 6). Micro-enterprise players only need to register themselves and their business products as members, then immediately get a membership card as proof that the micro-enterprise actor is entitled to various services provided by the Indonesian Government through the Cooperative Micro-enterprise Service, such as assistance services, training, capital, and digital marketing.

Table 6. Criteria and Requirements for Micro-enterprises to Participate in the Digital Marketing Program

\begin{tabular}{|c|l|c|l|}
\hline No & \multicolumn{1}{|c|}{ Criteria } & No. & \multicolumn{1}{|c|}{ Requirement } \\
\hline 1 & $\begin{array}{l}\text { The customer is an Indonesian citizen } \\
\text { (proven by an Indonesian id) }\end{array}$ & 1 & Photocopy of the applicant's identity \\
\hline 2 & $\begin{array}{l}\text { The customer has business assets of less than Rp. 300 million } \\
\text { (entered in micro-enterprise size) }\end{array}$ & 2 & Photocopy of financial statements \\
\hline 3 & $\begin{array}{l}\text { Has obtained a written recommendation from the District } \\
\text { Office in Indonesia }\end{array}$ & $\begin{array}{l}\text { Do not have loan arrears at the Indonesian Cooperatives and } \\
\text { Micro-enterprise Service (blacklist) or other financial } \\
\text { institutions }\end{array}$ & $\begin{array}{l}\text { Proof of micro-enterprise registration } \\
\text { (obtained from the nearest District } \\
\text { Office) }\end{array}$ \\
\hline 5 & $\begin{array}{l}\text { Willing to register their business products in an electronic } \\
\text { catalogue created by the Indonesian Cooperative and Micro- } \\
\text { enterprise Service }\end{array}$ & 5 & Copy of the applicant's family card \\
\hline
\end{tabular}

Source: (Ministry of Cooperatives and Small and Medium Enterprises, 2019), modified.

The success of adopting digital marketing programs implemented by Indonesian Microenterprise in marketing products digitally is a challenge for the Government to demonstrate organizational capabilities and benefits in facilitating micro business actors to survive the pandemic era while increasing their competitiveness to the international level. The process of adopting a digital marketing program in Figure 2 consists of several systematic stages intending to be a patent model for all micro-enterprises actors to develop their market share by adapting to technological advances and increasing welfare. Besides, the successful realization of the digital marketing adoption model for Indonesian Micro-enterprise can be used as a benchmark for other developing country governments to apply. The welfare of Microenterprise will also increase by implementing sophisticated technology.

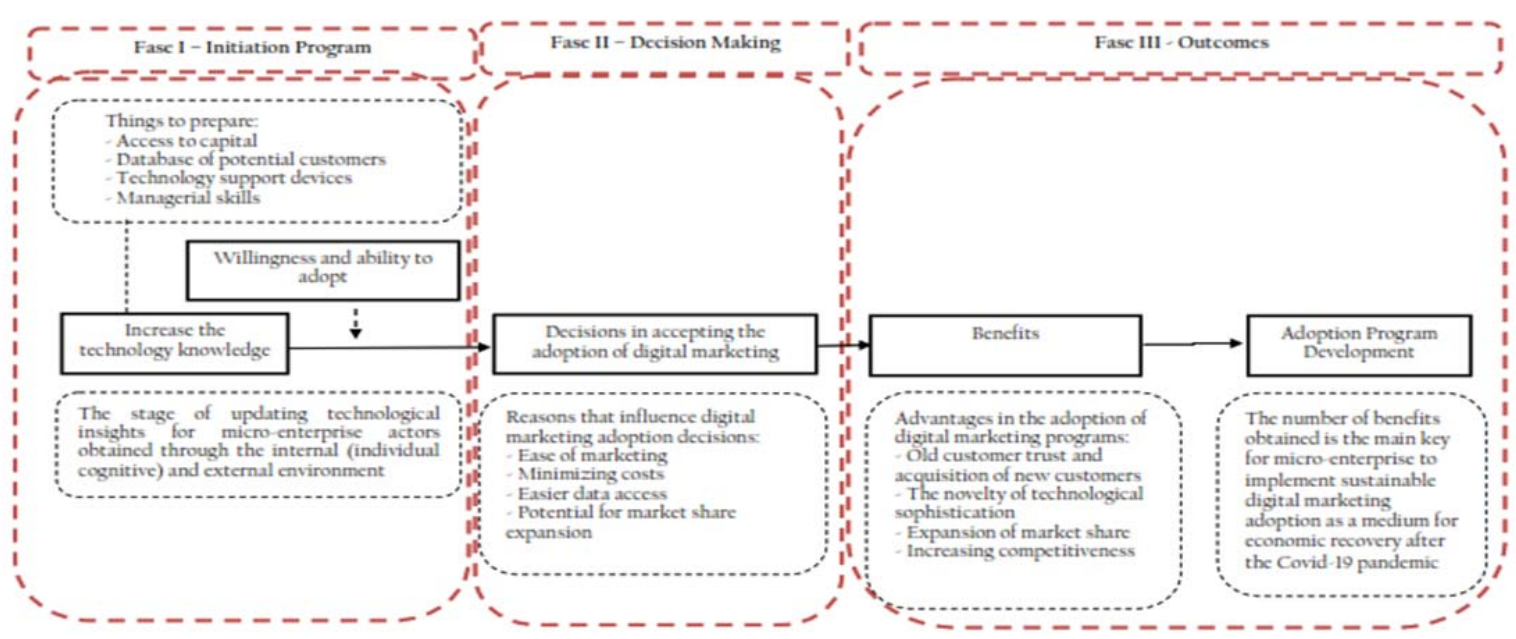

Figure 2. Roadmap for the Digital Marketing Adoption Program 
Three stages has to be followed systematically as a means in the program adoption process, including:

\section{Initiation Phase}

The initiation phase consists of activities related to recognizing needs, awareness of existing innovations, and identifying innovations that suit Indonesia's micro-enterprises' needs. So, indirectly, micro-enterprise players in Indonesia learn about innovation from their business strategy by considering their business objectives. Development at this stage plays a role in introducing technological insights to micro-enterprises to register and access programs to digital marketing. There are two things to emphasize at this stage, information retrieval and processing. When micro-enterprise actors in Indonesia can master these two things, it can reduce uncertainty in carrying out the program adoption process. The media used comes from environmental and individual factors, where individual factors come from self-awareness, meaning that all information obtained comes from micro-enterprise actors themselves by seeking information from various sources. The development of technological insights obtained by themselves will facilitate their business activities. Meanwhile, the environmental factors referred to are business partners, business associates, and their closest relatives, making micro-enterprise players more confident in deciding on program adoption. The right information selection can provide an overview of how the adoption of this technology can help run its business through electronic catalog media. So that from the point of view of the microenterprise actors, they will be optimally prepared to be able to master technology in program adoption, because when micro-enterprise actors are not ready to apply this new technology, the performance of the program will be less than optimal.

\section{Decision Making Phase}

Through the program, the Government of Indonesia hopes that there will be an increase in sales of products from micro-enterprise due to the broader market access to reach more consumers from government agencies in Indonesia or individually both inside and outside Indonesia. This factor is the basis for decision making in adopting the program. Ease of searching for the desired product through the internet network, where consumers only need to enter the keyword for their business product or the business actor's name will appear on the search page. So that consumers can shop anywhere, anytime, and according to their needs. The program's function as digital marketing enables micro-enterprise players to survive in a sluggish economic condition due to the Covid-19 pandemic. Besides, if business actors start to adopt the program, it will also help microenterprises minimize operational costs because everything is diverted online. Micro-enterprises' data access will also be more comfortable because the sophistication of technology helps micro-enterprise players obtain the data they need, starting from market data, the number of competitors, and suppliers of raw materials potential than today.

\section{Outcome's phase}

At the last stage in the program adoption mechanism, micro-enterprise actors get the benefits they need after adopting this program, such as increasing the number of orders, effective promotional media for business products, and ease in attracting consumers from outside Indonesia. Besides, micro-enterprise players also benefit from the novelty of technology in their business practices that have never been owned. Increased industrial competition has become more competitive because micro-enterprise players can survive in a sluggish economic condition due to the Covid-19 pandemic.

The adoption scheme for this program was prepared by the Government of Indonesia so that in its implementation, it will make it easier for buyers and sellers to make transactions while providing a sense of security and comfort (see Figure 3 and Table 7). 
Table 7. Overview of the Digital Marketing Program Adoption Scheme

\begin{tabular}{|c|c|c|}
\hline Stages & Function & Mechanism \\
\hline \multirow{2}{*}{ 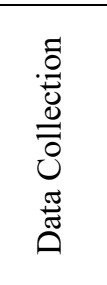 } & $\begin{array}{l}\text { ata collection on } \\
\text { nembership of micro- } \\
\text { nterprise players in }\end{array}$ & \multirow{2}{*}{$\begin{array}{l}\text { - Micro-enterprise actors submit applications for membership of the } \\
\text { program at the nearest sub-district office with registration } \\
\text { requirements } \\
\text { - Sub-district offices verify data and input data into the program system } \\
\text { The sub-district office prints membership cards and hands them over } \\
\text { to micro-enterprise actors and explains their rights and obligations as } \\
\text { members }\end{array}$} \\
\hline & istrict Uince & \\
\hline \multirow{4}{*}{.0. } & $\begin{array}{l}\text { Register an account } \\
\text { with the Program as a } \\
\text { buyer }\end{array}$ & \multirow{2}{*}{$\begin{array}{l}\text { - The buyer (regional organization or individual) registers a program } \\
\text { account as an administrator and enters the requested identity } \\
\text { - Data verification by the Government of Indonesia through the Office } \\
\text { of Cooperatives and Micro-enterprises } \\
\text { - The buyer logs in by entering the registered username and password } \\
\text { to make a purchase transaction } \\
\text { - To make it easier, download the program application on the Playstore } \\
\text { or Appstore so that it can be used anytime and anywhere. }\end{array}$} \\
\hline & $\begin{array}{l}\text { Responsible party: } \\
\text { regional organizations } \\
\text { and individuals }\end{array}$ & \\
\hline & $\begin{array}{l}\text { Register an account } \\
\text { with the Program as a } \\
\text { seller }\end{array}$ & \multirow{2}{*}{ 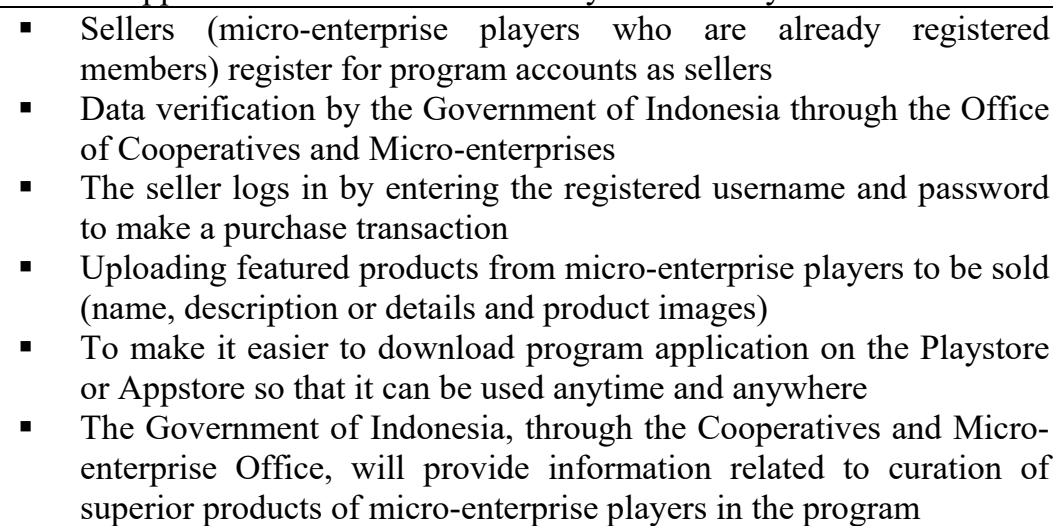 } \\
\hline & $\begin{array}{l}\text { Responsible party: } \\
\text { Micro-enterprise actor } \\
\text { who has been } \\
\text { registered as a member }\end{array}$ & \\
\hline \multirow{2}{*}{ 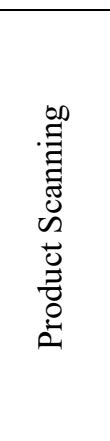 } & $\begin{array}{l}\text { products that will be } \\
\text { displayed in the } \\
\text { Program are of good } \\
\text { quality and clear and } \\
\text { complete product } \\
\text { information }\end{array}$ & \multirow{2}{*}{$\begin{array}{l}\text { - After the micro-enterprise players upload their superior products, it } \\
\text { will be verified by the Government of Indonesia through the } \\
\text { Cooperative and Micro-enterprise Office } \\
\text { Micro-enterprise players who pass the verification bring their product } \\
\text { samples to the Cooperative and Micro-enterprise Office for curation. } \\
\text { The curator will take product photoshoot, check, present the } \\
\text { packaged product, even taste the taste for assessment and suggestions } \\
\text { if necessary, so that product quality is guaranteed. }\end{array}$} \\
\hline & $\begin{array}{l}\text { Responsible party: } \\
\text { Government of } \\
\text { Indonesia, Office of } \\
\text { Cooperatives and }\end{array}$ & \\
\hline \multirow{2}{*}{ 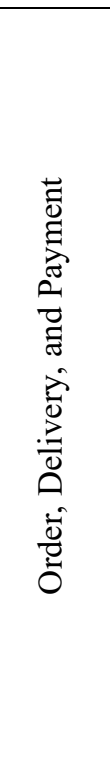 } & $\begin{array}{l}\text { Perform a search, } \\
\text { order, and delivery of } \\
\text { products from micro- } \\
\text { enterprise players as } \\
\text { needed }\end{array}$ & \multirow{2}{*}{$\begin{array}{l}\text { - The curator states that he has passed or rejected the products of the } \\
\text { micro-enterprise actors and hands back the assessed products to the } \\
\text { Micro-enterprise } \\
\text { Buyers log in using their username and password into the program } \\
\text { and search for the required product } \\
\text { - After getting the product, the buyer orders the required product } \\
\text { The invoice is received by the micro-enterprise actor and verifies that } \\
\text { the product order is capable or available for the buying and selling } \\
\text { process } \\
\text { The Office of Cooperatives and Micro-enterprises changes the status } \\
\text { of "message" to "received" and will be sent to the buyer's account } \\
\text { The buyer makes an advance payment, and the product order is } \\
\text { executed } \\
\text { Micro-enterprise actors work on orders and are ready to send them to } \\
\text { buyers according to the invoice received } \\
\text { The buyer receives products which have been ordered from the } \\
\text { system and signs a letter of receipt on invoice } \\
\text { Buyers make payments to micro-enterprise actors } \\
\text { The Department of Cooperatives and Micro-enterprises changes the } \\
\text { status from "received" to "done" and will be sent to the buyer's } \\
\text { account }\end{array}$} \\
\hline & $\begin{array}{l}\text { Responsible parties } \\
\text { Buyer, seller, and } \\
\text { Government of } \\
\text { Indonesia, Office of } \\
\text { Cooperatives and } \\
\text { Micro-enterprises }\end{array}$ & \\
\hline
\end{tabular}

Source: Primary Data, 2020. 


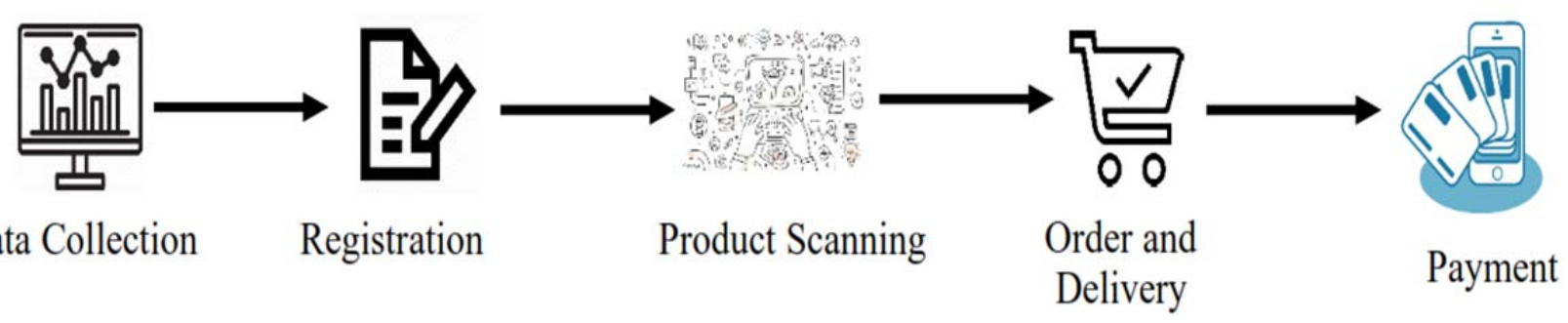

Figure 3. The Scheme of Digital Marketing Adoption Program

\section{The suitability of the Digital Marketing Program with Indonesia's 2015-2025 Long Term Development Plan}

Micro-enterprise in Indonesia has an increased potential for strategic value by adopting digital marketing programs to increase regional economic competitiveness. Historically, Indonesia is one of the commercial cities in Indonesia. This information based on Indonesia having a comparative advantage in supporting its regional economy because it is the center of government in Indonesia, and its location is quite central from the intersection of economic lines in various cities or other districts, as well as adequate services supported by good facilities and infrastructure, from land, sea and air routes. However, the Indonesian government also needs to increase its competitive advantage by maximizing existing economic opportunities that can be maximally managed and produced includes initiating a digital marketing program by the Government of Indonesia through the Cooperatives and Microenterprise Agency to optimize potential micro business actors in adopting digital-based marketing. The micro-enterprise can reach maximum performance of adopting the digital marketing program if Indonesia Government and realize every stage of digital marketing adoption maximally in the short, medium and long term. This program is closely related to the broader community, especially Microenterprise, and determining the development strategy it will provide an overall multiplier effect for the regions, especially the community, effectively and efficiently. Meanwhile, the implementation order requires the stakeholders' preparation and readiness to be determined by strong and consistent support and commitment in carrying it out.

In the Long-Term Development Plan (2005-2025), Indonesia's regional economic sector, especially in increasing regional independence and competitiveness, is prioritized on increasing the potential for regional economic capacity based on competitive and comparative advantages, which are based on local economic potential so that it can be competitive at the local, national and international levels (see Table 8).

Table 8. Targets, Directions and Priorities for Economic Development Based on Indonesia's Long-Term Development Plan

\begin{tabular}{|c|c|}
\hline $\begin{array}{l}\text { Policy Objectives and } \\
\text { Directions }\end{array}$ & Economic Development Priorities \\
\hline $\begin{array}{l}\text { First Five Years } \\
\text { (2005-2010) } \\
\text { Achievement of } \\
\text { development targets for } \\
2005-2010\end{array}$ & $\begin{array}{l}\text { - Increase the national economy by developing economic potential in superior } \\
\text { - Inational products } \\
\text { Increase the quality of superior products through the use of technology, } \\
\text { - Institutions and other supporting infrastructure } \\
\text { Increase the program environment between micro-enterprises and national } \\
\text { financial institutions to provide alternative funding to develop national } \\
\text { entrepreneurship } \\
\text { Increase investment and access to markets through revitalization and protection } \\
\text { of traditional markets as a strategy to support growth in the real sector and } \\
\text { provide opportunities for market development }\end{array}$ \\
\hline $\begin{array}{l}\text { Second Five Years } \\
\text { (2011-2015) } \\
\text { Re-strengthening } \\
\text { development priorities } \\
\text { following planned } \\
\text { implementation }\end{array}$ & $\begin{array}{l}\text { - Increase the structure of the potential national economy through the development } \\
\text { of economic potential in superior national products } \\
\text { - Development of superior product quality through appropriate technology, } \\
\text { institutional enhancement and other supporting facilities. } \\
\text { - Development of potential micro-enterprise players through national financial } \\
\text { institutions to meet market needs, develop entrepreneurship, and promote } \\
\text { national competitiveness. } \\
\text { Development of investment and access to markets to encourage growth in the } \\
\text { real sector economy by initiating traditional and modern markets. }\end{array}$ \\
\hline $\begin{array}{l}\text { Five Third Years } \\
(2016-2020)\end{array}$ & $\begin{array}{l}\text { - Enhance the structure of the national economy through the development of } \\
\text { potential sectors and superior national products }\end{array}$ \\
\hline
\end{tabular}




\begin{tabular}{|c|c|}
\hline $\begin{array}{l}\text { The consolidations of } \\
\text { development as a whole } \\
\text { which emphasizes the } \\
\text { achievement of } \\
\text { competitiveness }\end{array}$ & $\begin{array}{l}\text { - Strengthen the industrial sector in order to produce products that have } \\
\text { competitive and comparative advantages through strengthening the institutional } \\
\text { capacity of the business sector } \\
\text { - Strengthen the market-oriented micro-enterprise sector and developing the local } \\
\text { economy as well as strengthening the functions of national financial institutions } \\
\text { - Strengthen access to traditional and modern markets both domestically and } \\
\text { globally to increase economic growth and expand employment opportunities }\end{array}$ \\
\hline $\begin{array}{l}\text { Five Fourth Year } \\
\text { (2021-2025) } \\
\text { The implementation of the } \\
\text { sustainability achievement } \\
\text { of the 2005-2015 } \\
\text { development through } \\
\text { acceleration in various } \\
\text { fields, one of which is to } \\
\text { form a strong structure of } \\
\text { social, cultural and } \\
\text { economic life of the } \\
\text { community by taking into } \\
\text { account comparative and } \\
\text { competitive advantages }\end{array}$ & $\begin{array}{l}\text { - Increase the structure of the national economy through the development of } \\
\text { national potential and superior products } \\
\text { - Consolidate the quality and marketing of potential products that have competitive } \\
\text { and comparative advantages } \\
\text { - Strengthen micro-enterprise players with competitive and comparative } \\
\text { advantages in the information technology-based global market } \\
\text { - Consolidate sustainable national economic conditions } \\
\text { - Consolidate access to traditional and modern markets both domestically and } \\
\text { globally }\end{array}$ \\
\hline
\end{tabular}

Source: (Indonesian Planning and Development Agency, 2005).

The micro-enterprise sector's improvement can be realized if the Government of Indonesia pays attention to four strategic issues that are weak points for micro-enterprise actors in Indonesia following the National Long-Term Development Plan (2016-2021) (see Figure 4). Through programs, they tend to focus on developing innovation and competitiveness caused by the added value of production by microenterprises because they are closely related to the adoption of digital-based marketing. This program's success will contribute significantly to increasing production capacity, funding sources, innovation capacity, and the ability to develop superior national products.

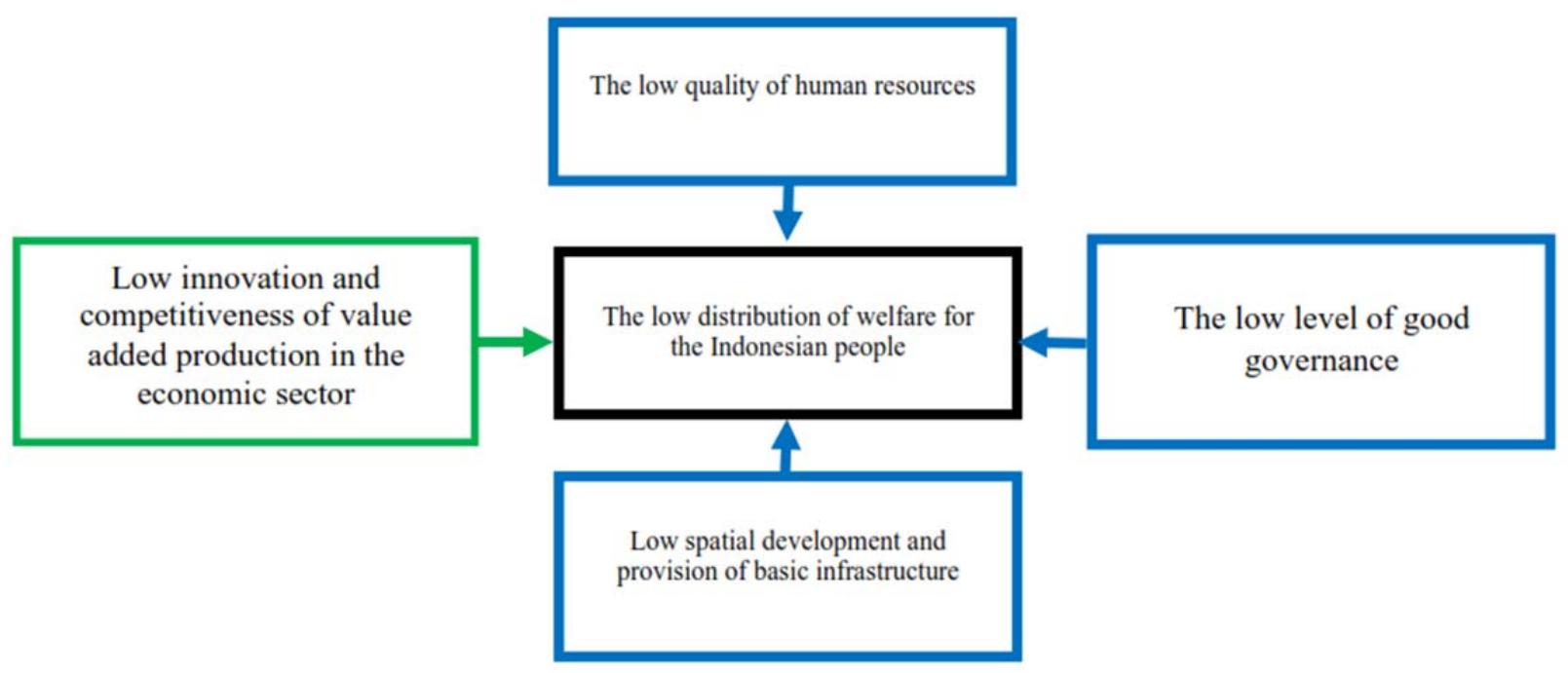

Figure 4. Critical Issues in Development in Indonesia Based on Long-Term Development Plans (2016-2021)

\section{Conclusion}

The digital marketing adoption program is implemented by the Government of Indonesia for micro-entrepreneurs to help them develop their businesses in order to survive in the pandemic era and increase their competitiveness to the national level. The advantages of digital marketing programs include (1) making it easier for Indonesian micro- entrepreneurs to become members; (2) increasing the trust of old customers and acquiring new customers; (3) has a business novelty in technological sophistication; (4) expanding market share and (5) increasing competitiveness. The benefits obtained by micro-enterprise actors have made more and more micro business actors decide to join as members of this program so that the digital marketing adoption program can be optimally utilized as an alternative 
recovery solution in the Indonesian micro-enterprise sector. However, there are still weaknesses in the digital marketing adoption program implemented by the Government for Indonesian micro-enterprise, which is that it only focuses on digitizing marketing programs but has not yet been integrated into other business processes.

Based on the results of the analysis of the advantages and disadvantages of this digital marketing adoption program, the Government of Indonesia through the Office of Cooperatives and Micro Enterprises can consider this idea to be applied to micro-enterprise actors who have met the requirements in order to improve their performance and expand market share. Besides, this digital marketing adoption program can also be patented and realized by other developing country governments to facilitate micro business actors to survive in the Covid-19 pandemic era and improve their welfare. If the use of this program is applied to other countries, it will positively impact the contribution of the Indonesian Government at the international level.

\section{References}

[1]. Worldometers.(2020). “Covid-19 Coronavirus Outbreak," Retrieved from: www.worldometers.info [accessed: 19. June 2021].

[2]. Wang, C. N., \& Le, A. L. (2018). Measuring the Macroeconomic Performance among Developed Countries and Asian Developing Countries: Past, Present, and Future. Sustainability, 10(10), 1-18. doi: 10.3390/su10103664.

[3]. Ginting, A. M., Hamzah, M. Z., \& Sofilda, E. (2019). The impact of fiscal decentralization on economic growth in Indonesia. Economic Journal of Emerging Markets, 11(2), 152-160.

[4]. Gamage, S. K. N., Ekanayake, E. M. S., Abeyrathne, G. A. K. N. J., Prasanna, R. P. I. R., Jayasundara, J. M. S. B., \& Rajapakshe, P. S. K. (2020). A review of global challenges and survival strategies of small and medium enterprises (SMEs). Economies, 8(4), 1-24. doi: 10.3390/ECONOMIES8040079.

[5]. Adebisi, S. A., \& Bakare, N. A. (2019). Survival Strategies and Sustainability of Small and Medium Enterprises in a Volatile Environment. Management Dynamics in the Knowledge Economy, 7(4), 553-570. doi: 10.25019/mdke/7.4.07.

[6]. Maksum, I. R., Rahayu, A. Y. S., \& Kusumawardhani, D. (2020). A Social Enterprise Approach to Empowering Micro, Small and Medium Enterprises (SMEs) in Indonesia. Journal of Open Innovation: Technology, Market, and Complexity, 6(3), 1-17. doi: 10.3390/JOITMC6030050.

[7]. Qashou, A., \& Saleh, Y. (2018). E-marketing implementation in small and medium-sized restaurants in Palestine. Arab Economic and Business Journal, 13(2), 93-110. doi: 10.1016/j.aebj.2018.07.001.
[8]. Alves, H., Fernandes, C., \& Raposo, M. (2016). Social media marketing: a literature review and implications. Psychology \& Marketing, 33(12), 10291038. doi: 10.1002/mar.20936

[9]. Morris, L. (2013). Three dimensions of innovation. International management review, 9(2), 510.

[10]. Horn, C., \& Brem, A. (2013). Strategic directions on innovation management-a conceptual framework. Management Research Review, 36(10), 939-954. doi: 10.1108/MRR-06-2012-0142

[11]. Tambunan, T. (2019). Recent evidence of the development of micro, small and medium enterprises in Indonesia. Journal of Global Entrepreneurship Research, 9(1), 1-15. doi: 10.1186/s40497-018-0140-4.

[12]. Afifah, A. N., \& Najib, M. (2018). Digital marketing adoption and the influences towards business successes of MSMEs creative sector in Indonesia and Malaysia. Jurnal Aplikasi Manajemen, 16(3), 377386.

[13]. Ritz, W., Wolf, M., \& McQuitty, S. (2019). Digital marketing adoption and success for small businesses: The application of the do-it-yourself and technology acceptance models. Journal of Research in Interactive Marketing, 13(2), 179-203. doi: 10.1108/JRIM-04-2018-0062.

[14]. Igwenagu, C. (2016). Fundamentals of research methodology and data collection. LAP Lambert Academic Publishing.

[15]. Rwigema, P. C. (2020). Effect of covid-19 on micro, small and medium enterprises (MSMEs) in Rwanda. The Strategic Journal of Business \& Change Management, 7(4), 1630-1655.

[16]. Juwita, R., Arsyad, A. W., \& Alfando, J. (2020). MSMEs Empowerment Communication in New Normal Era: The Case of Mini University Kaltim Preneurs in East Kalimantan, Indonesia. Budapest International Research and Critics Institute (BIRCIJournal): Humanities and Social Sciences, 3(4), 37543765. doi: 10.33258/birci.v3i4.1439 3754

[17]. Clauss, T., Bouncken, R. B., Laudien, S., \& Kraus, S. (2019). Business Model Reconfiguration And Innovation In Smes: A Mixed-Method Analysis From The Electronics Industry. International Journal of Innovation Management (ijim), 24(02), 1-35. doi: $10.1142 / \mathrm{S} 1363919620500152$.

[18]. Redjeki, F., \& Affandi, A. (2021). Utilization of Digital Marketing for MSME Players as Value Creation for Customers during the COVID-19 Pandemic. International Journal of Science and Society, 3(1), 40-55. doi: 10.200609/ijsoc.v3i1.264

[19]. Wilson, M. S. (2020). A real business cycle model with money as a sunspot variable. Journal of Economics and Business, 109, 105891. doi: 10.1016/j.jeconbus.2020.105891.

[20]. Müller, J. M. (2019). Business model innovation in small-and medium-sized enterprises: Strategies for industry 4.0 providers and users. Journal of Manufacturing Technology Management, 30(8), 1127-1142. doi: 10.1108/JMTM-01-2018-0008. 